\title{
Total Ergonomics and Its Impact in Musculoskeletal Disorders and Quality of Work Life and Productivity
}

\author{
Naser Sadra Abarqhouei ${ }^{{ }^{*}}$, Hasan Hossaini Nasab ${ }^{2}$ \\ ${ }^{1}$ Institute of Higher Education and Applied Science, Jihad of Agriculture, Yazd, Iran \\ ${ }^{2}$ Faculty of Industrial Engineering, University of Yazd, Yazd, Iran \\ E-mail: *nasersadra@yahoo.com \\ Received September 6, 2011; accepted November 2, 2011; accepted November 10, 2011
}

\begin{abstract}
Studies have indicated the application of ergonomics in improving the quality of work life, reducing musculoskeletal disorders and increasing productivity. On the other hand, there are large differences between developing and developed countries in applying ergonomics knowledge, the need of applying the science of culture, especially in developing countries and the third world is vital, but the culture implementation and pay evaluation of total ergonomics (micro and macro) is low. Therefore, this study has tried using the studies of society and culture dominated by manufacturing service, a comprehensive and integrated model for ergonomics interventions to be developed and used in an educational establishment and the effects of ergonomic interventions in a field study in comparison with conditions before the intervention using questionnaire "body mapping" and "quality of work life" to evaluate. Study results showed increased productivity, improved work life quality and reduced musculoskeletal disorders. So a comparison of performance than the base year indicated lower costs and increased revenue and expanded with less manpower in data analysis questionnaire "quality of work life" and "body mapping" which showed that significant difference in confidence interval between the sample and control population is ninety-nine percent and there is reduction of musculoskeletal disorders and increase in quality of work life. Those indices indicated the positive effect of interventions ergonomics.
\end{abstract}

Keywords: Micro Ergonomics, Macro Ergonomics, Quality of Work Life, Musculoskeletal Disorders, Productivity

\section{Introduction}

Ergonomic studies have shown systems with weak designing, neglected ergonomic principles and have brought staff and workers disorders. Not considering to the ergonomic principles at work can provide spiritual and physical tensions, low productivity and unsuitable work life quality and effective execution of ergonomic programs and increasing ergonomic awareness [1]. Nowadays improving productivity has been recognized as one of the most important cultural and socio-economic development alternatives as access to success in speeding productivity improvement is one of main conditions of access to suitable place in world competition and improving people's life [2].

Based on the fourth and fifth country development program, getting into real economic fact and continuous growth, at least $8 \%$ of Gross Domestic Product (GDP) is annually increasing the productivity in economic growth. This has been forecast to one third at the end of the fifth program and improving judiciary and administrative system for increasing movement and efficiency, improving service delivery to people, assuring staff livelihood, increasing indices of work and life environment and spiritual and physical hygiene. These legal necessities have made sensitive execution organizations and economic directors of country and provinces by using different tools and methods to think about providing important principles in the fourth and fifth development programs in their economic units and sectors. Since results of different researches have shown logical and positive impact on applying productivity and total ergonomic knowledge, efficient development, maintaining human rights, welfare, social security, relative increase of per capita income, thought innovation and so on ${ }^{1}$, undoubtedly making cul-

${ }^{1}$ Refer to Section 2 (research topic literature). 
ture and using ergonomics in Iran can help the country to achieve important goals in cultural and socio-economic programs which have been determined for achieving vision of country. Unsuitable work life created under unsuitable work with humans provides imbalance between social and psychic conditions of staff of organization, only not considering goals of organization, but also causes decrease in productivity, increase in absence, displacing and leaving work (Figure 1) and finally causes low selfconfidence in labor force. Such conditions affect on quality and as a result work life in organizations and production centers, make work life unsuitable and repeat events and insecurity [3].

\section{Review of Research Literature}

The goal of applying ergonomics is to provide a logical and suitable relationship among staff and their work. Ergonomics can study workers psychology and physiology at work with a complicated system among humans, tool and environment [1]. Improving productivity is an easy method for encouraging management in costs, programming and using ergonomic intervention and it can be more effective for a person without ergonomic information or a person not working on staff health and safety section, productivity provides a common language among stockholders [4]. In spite of many studies in recent decades about ergonomics, many factors in organizations cause musculoskeletal disorders and ergonomic costly diseases [5,6], which show that ergonomic changes have not achieved the useful effectiveness in producing environment [7], thus all attempts of ergonomic researchers should be coordinated in decreasing ergonomic risk factors and as a result improving quality of work life practically and usefully. The conducted researches show that distributing ergonomics knowledge among staff is for helping and better execution of service and production programs. The results of conducted study show that ergonomic uses in designing tools will provide much effect on psychic health, work satisfaction, increasing efficiency, security and health [8] and as a result it will improve work life.

An efficient and effective system, which is the base of a productive system, depends on the manner of service delivery by human operators. We cannot imagine that human force is an island among service and production processes [9]. In an efficient and effective system, more attention should be given to human force and it should be tried to decrease human errors meanwhile providing staff health and safety, and it can be done by choosing suitable persons and training, designing equipments, work environment and tools by considering physical and spiritual needs and characters of humans, providing methods and logical agenda [10]. It is clear that by achieving these

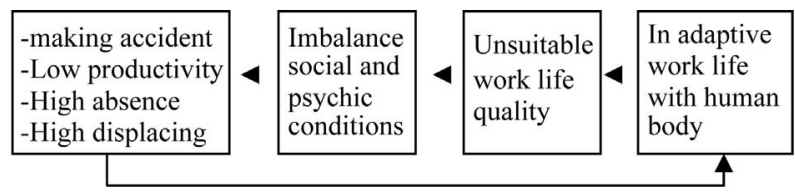

Figure 1. Effects of unsuitable work on human body.

goals and providing work welfare for human force working at service and producing systems, we can observe increased productivity indices and quality of work life in service and production organizations. The concept of quality of life refers to Aristotle era (385 years B.C.). At that era, Aristotle considered "good life" or "doing work well” in meaning of being happy. The word of quality of life was used for the first time in 1920 in the book "Economics and Welfare” [11]. In 1985, in northwest of England, life quality researches were conducted for the first time. These researches provided a complete definition of life quality: a person understands from his or her situations with respect to living value system and culture and relationship of these captures with intended goals, expectation, standards and priorities [11].

Having a healthy and quality life with acceptable life expectancy and without disease and inability is a general right and pre-condition for achieving sustainable development of any country [12].

Potential ability of macro-ergonomics in considerable improvement of organizational functioning involving hygiene, safety, job satisfaction, quality of work life and productivity has been considered recently. As it was said before, introducing and clear show of this potential ability will cause wide support by using and developing macro ergonomics technology [13]. For achieving the suitable situation, it is necessary that considerable changes one made in field of ergonomic research and training and making culture by moving from a safety and hygiene pattern of ergonomics to a work pattern of ergonomics without missing safety and health goals [14]. In this respect, Dempsey (2007) conducted a research under the title of "ergonomic interventions for preventing musculoskeletal disorders” and understood many obstacles in way of this study [4].

For optimum design of system with the goal of facilitating recognition and access the needs of consumers, it seems necessary to integrate human factors in start of design cycle till work life [15]. Human factors engineering specialists worry about design and relationship between system items for improving health, safety, comfort ability, quality of production and decrease in design problems. The global attention towards human factors engineering is increasing human life quality [16].

If directors are satisfied that improving ergonomics meanwhile providing professional hygiene and safety rules simultaneously can help in achieving strategies and 
goals of organizations, its acceptance among directors will be easier [14,17]. Thus, relating ergonomics with organizational strategies can associate management with a positive motivation for executing ergonomics. The general strategies used in model design include:

1) Micro ergonomics strategy concentrated on system of humans, machine, environment and work and its goal is to improve work or computer for preventing danger in daily performance of system.

2) Macro ergonomics strategy focused on organization and its goal is socio-technical system optimization and study of effect of organization structure on safety and human behavior [18,13].

Macro ergonomic is integrated from general principles of quality management [19] and focuses on needed conditions for improving a system. Macro ergonomic effects include:

- Effect on number, training and satisfaction of employees,

- Effect on quality and equipment survival,

- Effect on empowering physical environment,

- Effect on quality of work life,

- Effect on economic production,

It's not only an analysis method, but also a method for designing socio-technical systems by delivering systematic characters (common cross of technical fields and organization) [19]. It is clear that these two strategies focus on human and system and relationship which will get shape between these two strategies, and will affect on strategies and integration of system.

In organizational systems, close relationship with low level labor force of organization is considered, only important thing is that relationship among different levels of an organization can cause exact transmission of ergonomic information to superior directors and as a result it helps in better determination of production strategies. In stage of providing process, close relationship among different levels of organization management with zero level staff of organization, all ergonomic physiology and physical factors are considered and in feedback stage, all information related to ergonomic risk factors in all organization levels are transferred to organization superior directors and this recognition makes directors consider more programming for improving process of service delivery and motivation indices of staff including leaving work and also other indices including leaving work due to disease and delays and stop at work are decreased by considering ergonomic factors [4]. In this respect, staff participation and management support can have important role among different levels of organization for executing ergonomic goals.

Participatory ergonomics is a growing branch in macroergonomics and designing organization and management, and from beginning about three decades ago it has had growing attraction. In this field, to improve work environment conditions, productivity and quality, model of participatory ergonomics in a small industry was designed and executed in Iran [20]. On the other side, performance evaluation is one of the main duties of each organization and is one of performance management dimensions that in the past has been execute via using financial indices [21]. Efficient directors by relying on control systems and performance measurement in determining outlines, making strategic decisions and access to suitable goals conquer on problems. In these two decades some issues as determining factors of competitive advantage have been considered including organizational learning, creating knowledge and innovation capacity [22,23] and so organization should try for finding total indices of performance measurement, with more focus on soft performance (human) indices because the weakness or empowerment of mentioned indices, are not shown in balance-sheet [23].

One of soft performance indices not shown in balancesheet is effect of ergonomics use in organizations. Since in present era, human resources are considered as key factor for organizations success, we can deduce that power sustainability of an organization depends on physical and psychic health of its staff [24]. By correct use of control systems and measuring performance organizational obstacles can be captured that prevent appearing organization members ability [25]. In this respect, many valid ergonomics evaluation methods have been used with the goal of analyzing work environment (such as RULA [26], Strain Index [27], REBA [28] etc.). The considerable point is studies of these uses have been shaped in industries environment [29-31], but the reality is that industrial companies with related interior methods or prepared rules at national level like refusal or acceptance measurements are used for evaluation, as a result the number of research articles which study methods of using and evaluating ergonomics is very less [32]. On the other hand, conducted studies certify this reality that using ergonomic is effective in improving quality of work life, decrease in musculoskeletal disorders and increase in productivity and in attention to high difference of using ergonomics among developed and developing countries [9], it's necessary to make a culture of using this science specially in developing countries and the third world and since models of making culture, launching and evaluating integrated ergonomics, are very few [32], it is necessary to design total and integrated model based on the following goals:

1) Measuring ergonomics effect on productivity, decrease in musculoskeletal disorder and increase in quality of work life in organizations via designing and using a 
comprehensive and integrated model with logics of "monitoring”, "insisting” and "sustainability" in culture making and using based on management and knowledge supports, staff participation, evaluation, recognition and encouragement and communication and information network.

2) Providing basic field for performing applied ergonomic researches.

3) Helping in ergonomics culture extension in world.

4) Delivering performance evaluation model which can help to distribute culture of using ergonomics in the third world countries and advanced and developing countries.

\section{Materials and Methods}

This research is applied and analysis-descriptive study and by conducted studies and researches in field of different models of evaluation, emphasis solving models weak points by using concepts and goals of total ergonomics knowledge, as by using this model we can execute and evaluate ergonomics in different processes and work and to measure its effect on productivity, improving work life and musculoskeletal disorders decrease in organizations. Delivering model of interventions and evaluating total ergonomics and its effect on organizational productivity is done by studying and using conducted concepts and researches in performance evaluation field, micro and macro-ergonomics, relationship between macro-ergonomics, management and organizational designing and productivity. In this research by defining and recognizing society studies and launching ergonomics based on designed model and using analysisdescriptive statistics and questionnaire, delivered model is practically used towards determined goal in frame of a case study and necessary statistical tests are done.

\subsection{Designing and Introducing Model}

By considering issues in introduction and reviewing research literature, model designing is done based on five principles including management support, knowledge support, staff participation, evaluation, recognition, encouragement and communication and information network with logics of insistence and sustainability in culture making and launching total ergonomics and is delivered in frame of Figure 2.

\subsection{Method of Model Use}

The EO model was used in the experimental training center. This center, using more that 220 teachers and employees and 1000 students in different related courses

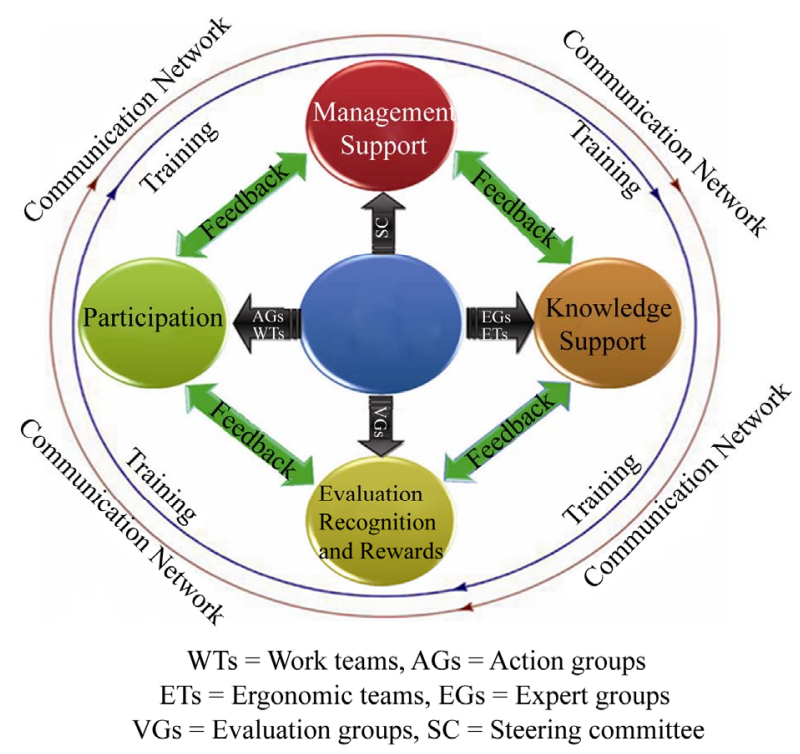

Figure 2. Model of interventions and evaluation process of total ergonomics.

like accounting and computer, became interested to execute interventions programs and ergonomic evaluation for performance improvement, and after several sessions got the responsibility for facilitating ergonomic use method in different sections management and supervision on project and guiding persons in process. Project under title "ergonomic interventions" at two stages i.e. micro and macro ergonomic interventions in framework of designed model, planning and is executed.

\subsection{Evaluation of the Total Ergonomic Interventions}

In this research, studying musculoskeletal disorders using body mapping standard questionnaire [33] is determined and analyzed. This questionnaire seeks user's disorder in five quality dimensions form non ergonomic and ergonomic chairs in 28 questions according to body division to 28 parts.

It's necessary to mention that used quality dimensions in body mapping questionnaire is integrate from SERVQUAL $^{2}$ model that for recognition and classification of people opinions has had the most use in management [34]. For studying the quality of work life in sample population (before and after the total ergonomic interventions), several questionnaires were prepared and delivered with the issue of quality of working life. These questionnaires were taken by Allameh (1999) from the National Institute of Occupational Safety and Health (NIOSH), based on the Dalton work life quality [35] and the present study was based on these questionnaires by

${ }^{2}$ Servqual model is one of the most famous service quality measuring methods mentioned in 1985. 
summarizing and considering the following arguments:

1) Questionnaire with Islamic culture governing on county has been designed.

2) Number of mentioned questions in this questionnaire is more than other questionnaires (77 five-choice questions).

3) Quality dimensions are as five-choice in answersheet coordinated with Servqual model which is total questionnaire and used in such researches.

\section{Results and Discussion}

The first stage of project includes process of using macroergonomics. The major goal at the first stage was to improve different systems and processes of service delivery to students and other trainees including stakeholders and EO centers staff in view of macro-ergonomics. Systems and processes like labs, students participation for delivering suggestions and performing work, evaluating process of service delivery to students, increasing quality of delivering classes, encouraging staff, alternatives for delivering recreational-welfare services, optimizing service and production section, human resources management and human force optimization process were considered in this study. Macro ergonomics interventions process was started by conducting a three-day workshop and 30 directors and staff participated in it. The workshop was held for finding a view to EO and regulating different goals for achieving a special vision of EO. A questionnaire was prepared and participants wanted to mention an EO vision and at least three main goals for achieving an understandable vision. The questionnaire were distributed, completed and collected, and then by summarizing mentioned issues in workshop, EO vision was determined at two items:

1) EO as the biggest and most important skill and higher education center at regional and national level.

2) Advancing EO in producing and processing products in framework of training pilots.

Then as in Table 1, delivered goals for achieving vision were summarized and approved.

For impressive use of staff and students in Ergonomic Interventions Program (EIP) via future workshop was used. Future Workshop (FW) is a socio-pedagogic method for identification of a common problem, development of a vision, ideas and action plan among a group of concerned people. Later on it was spread successfully to the Scandinavian countries and is now widely used as participatory intervention method [10]. Future Workshop is a well-structured process with five defined phases:

1) Preparation phase 2) Experience phase 3) Fantasy phase 4) Strategy phase 5) Action phase/Follow up.

This workshop started its work in the framework of
Table 1. Major goals for achieving vision.

\begin{tabular}{cl}
\hline 1 & $\begin{array}{l}\text { Recognizing new technologies in related section and } \\
\text { transferring them to students, stakeholders and official } \\
\text { experts in related section. }\end{array}$ \\
2 & $\begin{array}{l}\text { Improving quality of welfare cultural programs for students } \\
\text { and staff by improving methods and new investments. }\end{array}$ \\
3 & $\begin{array}{l}\text { Human resource management (optimizing human force) by } \\
\text { applying, maintaining, training and encouraging staff. }\end{array}$ \\
4 & $\begin{array}{l}\text { Improving chain of studies of students in discontinuous } \\
\text { expertise till professional PhD. }\end{array}$ \\
5 & $\begin{array}{l}\text { Increasing participation of parents and students for material, } \\
\text { intellectual and thinking help to EO. }\end{array}$ \\
6 & $\begin{array}{l}\text { Providing necessary background for delivering innovation in } \\
\text { performance and training program. }\end{array}$ \\
7 & $\begin{array}{l}\text { Applying and participation of students at EO production and } \\
\text { routine activities. }\end{array}$ \\
8 & $\begin{array}{l}\text { Improving culture of cooperation and participation of } \\
\text { students and staff of EO. }\end{array}$ \\
9 & $\begin{array}{l}\text { Developing training courses and admitting more students. } \\
10\end{array}$ \\
\hline
\end{tabular}

above phases (Figure 3) and studied the problems during four months and suggested solutions for solving them. The most suggested approaches are delivered for attracting participation of persons and using their potential capacities for solving problem and executive policies and programs delivered in future workshop (Table 2).

The delivered suggestions at macro-ergonomics interventions stage for ergonomic culture development and extension and also continuous improvement of processes and dangers and ergonomic risk factors in EO subsections were executed. EO superior management agreed with suggestion of execution of a process of micro ergonomic interventions for improving work situation and productivity increase as the second stage of ergonomic intervention process.

Also this stage was started with two-day workshop like the first stage. 35 persons among staff participated in workshop. The goal of workshop was to provide ergonomic awareness among participants and teaching methods of recognizing ergonomic risk factors related to improving environment and work situation. Workshop was started by introducing list of ergonomic inspection for increasing productivity, safety and comfort ability [36]. The project supervisor showed contents of list of ergonomic inspection including 79 inspections and explained to participants how to use it at their work place. Participants were divided into 7 different groups and each group studied 79 factors and tried to understand why and how to study factors and according to work experience, how to adjust to their work and explain it. Also they wanted to 


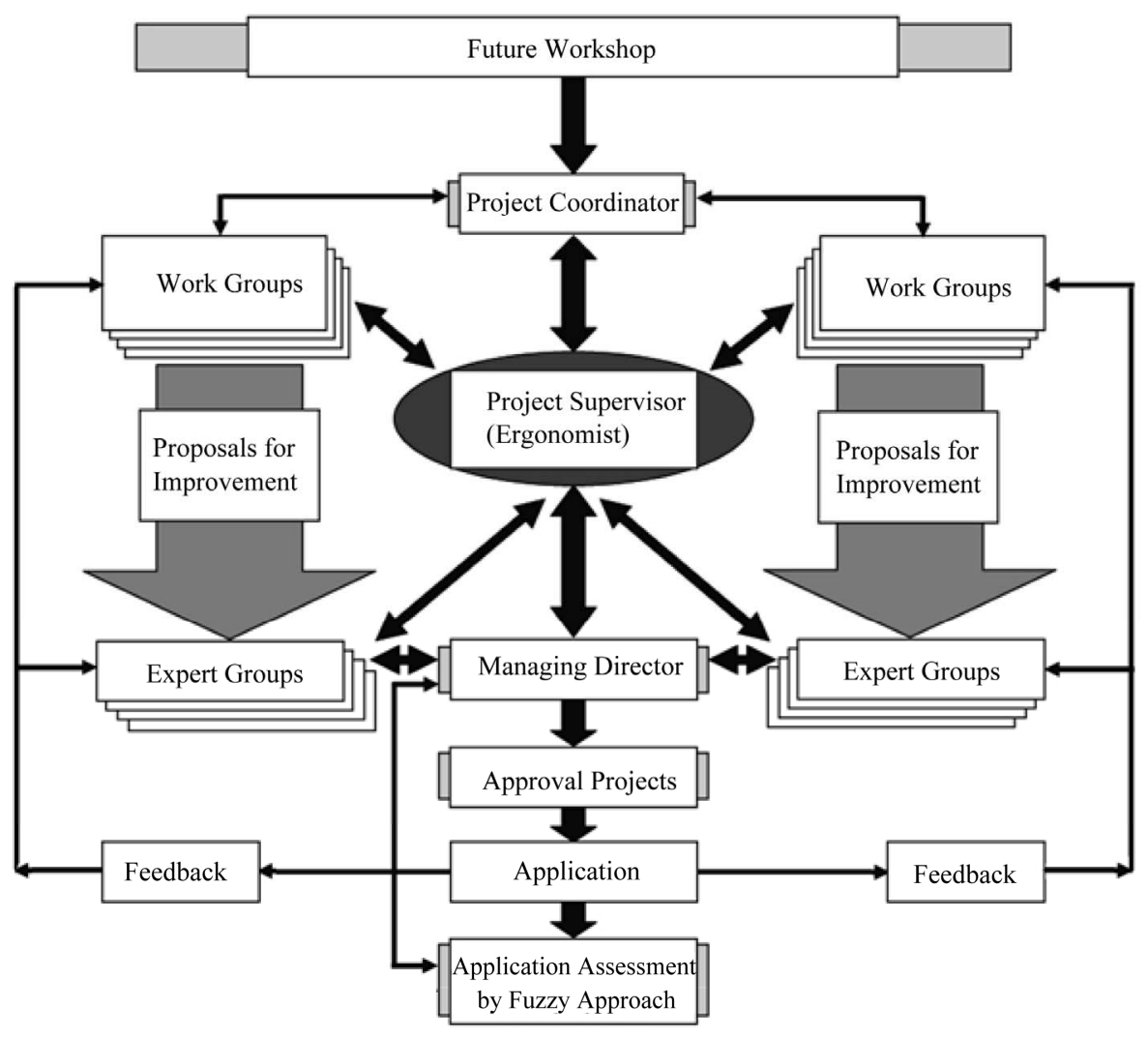

Figure 3. Activity diagram of ergonomics workshop for managers and leaders of instructional groups.

Table 2. Summarizing delivered executive policies and programs at future workshop.

\begin{tabular}{|c|c|}
\hline Row & Approved executive policies and programs titles \\
\hline 1 & $\begin{array}{l}\text { Organizing official place with the goal of decreasing musculoskeletal and physic stress via: } \\
\text { - } \quad \text { Extracting Iranian anthropometry and using it in designing theater salon, conference salon, computer salon, classes and etc. } \\
\text { - } \quad \text { Recognizing ergonomic risk factors, evaluating them and determining solution for problems. } \\
\text { - } \quad \text { Determining students and staff safety agendum and executing students insurance. } \\
\text { - } \quad \text { Programming and executing ergonomic training courses for scientific jury members and staff. } \\
\text { - } \quad \text { Forecasting seasonal common sessions and discussing about safety standards. } \\
\text { - } \quad \text { Emtroducing successful patterns and encouraging about considering ergonomic suggestions. }\end{array}$ \\
\hline 2 & Considering percent of EO income for active staff and students in delivering suggestions and EO income generation. \\
\hline 3 & Encouraging staff and students for providing cooperation culture and reminding more to EO. \\
\hline 4 & Providing necessary backgrounds to students for executing applied researches needed for related section. \\
\hline 5 & Empowering applied scientific relations with related section via opening relation office with industry at EO. \\
\hline 6 & Programming for research scientific relations among EO and applied scientific centers in and out of country. \\
\hline 7 & Preparing agendum and work plan of university and family cooperation society (university and parents society). \\
\hline 8 & Programming for using applied research findings for student's educational programming. \\
\hline 9 & Approving and establishing conference salon for using different trainings by considering ergonomic principles. \\
\hline 10 & Students’ skill based activities towards defining income generating projects and designs. \\
\hline 11 & Making relations with research centers and common execution of research projects. \\
\hline 12 & Equipping labs to modern tools and establishing specialized labs. \\
\hline 13 & Supporting innovations regarding related section in framework of growth centers. \\
\hline 14 & Providing data bank of world scientific findings in related section. \\
\hline 15 & Approving establishment of theater salon by considering ergonomic principles. \\
\hline 16 & Providing scientific societies and student foundation at EO. \\
\hline 17 & Programming for exchanging students with other countries. \\
\hline
\end{tabular}


write down the experiences about each studied point and if they have any executive suggestion regarding these activities, then different group persons were gathered and showed acquired results summary to each other and discussed about decisions for suggested activities and their priority and also suggested solutions for solving problems. After workshop, members of committee were chosen for preparing agenda or steering committee by project supervisor, project coordinator and EO superior manager.

In this committee three persons were chosen as EO superior director agents and then steering committee had a meeting and during some sessions discussed and approved duties and activities of steering committee and work teams, the most important actions done and defined at this stage for work teams, action groups and ergonomic group and steering committee are delivered in Table 3.

For measuring musculoskeletal disorders of sample society users' opinions were taken about intended chairs and tables thus after using them every two hours, they wanted to determine amount of disorder in each body part in five quality dimensions (without disorder, with less disorder, very less disorder, with much disorder, intolerable disorder) in body mapping 28 part questionnaire by writing from one to five.

Of 77 distributed questionnaires accidently among society persons, 65 questionnaires were completed and returned and of 133 distributed questionnaires among society persons with ergonomic interventions, 107 questionnaires were completed and returned then body mapping questionnaire data was summarized that has been shown in Table 4.

For measuring ergonomic interventions effect on quality of work life and recognizing sample society opinion (before and after ergonomic interventions) and classifying their opinion questionnaire of work life quality was used [35]. This questionnaire seeks person's opinion in 77 questions and in five qualitative dimensions. It's necessary to mention that used qualitative dimensions in this questionnaire is integrated from servqual model which has had the most use in management for recognizing and classifying person's opinion. Person's opinion was taken before and after ergonomic interventions in five qualitative dimensions (very less, less, average, high, very high) thus before executing ergonomic interventions program of sample society was chosen and then questionnaire was distributed among 58 individuals of sample society and 53 individuals of control society. Of which, 51 and 47 questionnaires were completed and returned. After ergonomic interventions (after 2 years) 57 and 54 questionnaires were distributed among sample and control society individuals that 49 and 45 questionnaires
Table 3. Executed projects and designs at micro ergonomic stage.

\begin{tabular}{cl}
\hline $\begin{array}{l}\text { Sr. } \\
\text { no. }\end{array}$ & $\begin{array}{l}\text { Plans and project titles implemented at micro ergonomics } \\
\text { stage }\end{array}$ \\
\hline 1 & $\begin{array}{l}\text { Designing and executing necessary projects for facilitating } \\
\text { trainings execution such as teaching classes at supported } \\
\text { forms. }\end{array}$ \\
2 & $\begin{array}{l}\text { Enriching staff work and basis of EO training and different } \\
\text { executive sections by combining parallel and similar works. }\end{array}$ \\
3 & $\begin{array}{l}\text { Extracting Iranian static anthropometry and using it for } \\
\text { optimizing and designing approved project. }\end{array}$ \\
4 & $\begin{array}{l}\text { Recognizing ergonomic risk factors, evaluating them and } \\
\text { choosing solution for solving ergonomic problems. }\end{array}$ \\
5 & $\begin{array}{l}\text { Holding ergonomic training courses for scientific jury } \\
\text { members and staff once in every three month. }\end{array}$ \\
6 & $\begin{array}{l}\text { Introducing successful patterns and researches and } \\
\text { encouraging staff for considering ergonomic suggestions. }\end{array}$ \\
7 & $\begin{array}{l}\text { Preparing students and staff safety agendum and executing } \\
\text { student insurance. }\end{array}$ \\
8 & $\begin{array}{l}\text { Forecasting seasonal common sessions and discussing about } \\
\text { safety standards. }\end{array}$ \\
9 & $\begin{array}{l}\text { Designing and installing turn-taking system and food } \\
\text { pre-purchase. }\end{array}$ \\
\hline
\end{tabular}

Table 4. Numbers calculated by collecting the community opinions with the help of sample and control community body mapping questionnaire qualitative dimensions.

\begin{tabular}{|c|c|c|c|c|c|c|}
\hline \multicolumn{3}{|c|}{$\begin{array}{c}\text { After ergonomic } \\
\text { intervention } \\
\text { (Sample community) }\end{array}$} & \multicolumn{3}{|c|}{$\begin{array}{c}\text { Before ergonomic } \\
\text { intervention } \\
\text { (Control community) }\end{array}$} & \multirow[t]{2}{*}{$\begin{array}{l}\text { Qualitative } \\
\text { dimensions }\end{array}$} \\
\hline$F_{i}$ & $n_{i}$ & $N_{i}$ & $F_{i}$ & $n_{i}$ & $N_{i}$ & \\
\hline 24.85 & 107 & 2658 & 20 & 65 & 1304 & No Discomfort \\
\hline 2.262 & 107 & 242 & 4.08 & 65 & 265 & Less Discomfort \\
\hline 1.35 & 107 & 144 & 2.91 & 65 & 189 & $\begin{array}{c}\text { Partial } \\
\text { Discomfort }\end{array}$ \\
\hline 0.4 & 107 & 43 & 1.523 & 65 & 99 & Much Discomfort \\
\hline 0.131 & 107 & 14 & 0.492 & 65 & 32 & Intolerable pain \\
\hline
\end{tabular}

$N_{i}=$ Response frequency to qualitative dimension; $i ; n_{i}=$ Community members undertaking questionnaire with performed ergonomic interventions and the control community (sample numbers); $F_{i}=$ Response frequency to qualitative dimension.

were returned and after summarizing data of questionnaire, necessary computations were done. The results have been given in Table 5 .

Total ergonomic evaluation in this research was done by two methods:

1) Studying musculoskeletal disorders and work life quality via body mapping questionnaire and work life quality study questionnaire [35].

2) Studying comparison performance before and after ergonomic intervention in different fields such as training, sports, culture and finance (number of students, number of delivered articles, getting research-scientific honors). 
Table 5. Conclusion of statistical data about the quality of work life, before and after the total ergonomic intervention.

\begin{tabular}{|c|c|c|c|c|c|c|c|c|}
\hline \multicolumn{4}{|c|}{$\begin{array}{l}\text { Sample and control populations } \\
\text { (After ergonomic interventions) }\end{array}$} & \multicolumn{4}{|c|}{$\begin{array}{l}\text { Sample and control populations } \\
\text { (Before ergonomic interventions) }\end{array}$} & \multirow{3}{*}{$\begin{array}{l}\text { Qualitative } \\
\text { dimensions }\end{array}$} \\
\hline \multicolumn{2}{|c|}{$F_{i}$} & \multicolumn{2}{|c|}{$n_{i}$} & \multicolumn{2}{|c|}{$F_{i}$} & \multicolumn{2}{|c|}{$n_{i}$} & \\
\hline control & sample & control & sample & control & sample & control & sample & \\
\hline 8.84 & 11.2 & 45 & 49 & 11.65 & 18.16 & 47 & 51 & Very less \\
\hline 22.53 & 12.37 & 45 & 49 & 29.86 & 16.84 & 47 & 51 & less \\
\hline 34.6 & 23.71 & 45 & 49 & 26.94 & 25 & 47 & 51 & Average \\
\hline 13.7 & 26.1 & 45 & 49 & 12.1 & 17 & 47 & 51 & High \\
\hline 3.33 & 9.62 & 45 & 49 & 2,45 & 6 & 47 & 51 & Very high \\
\hline 83 & 83 & - & - & 83 & 83 & - & - & Sum \\
\hline
\end{tabular}

$n_{i}=$ Sample size; $F_{i}=$ Response frequency to qualitative dimension/person.

\subsection{Significant Difference Test of Qualitative Dimensions}

For analyzing qualitative dimensions of control and sample society, $t$-test and Chi-Square test were used in the framework of contingency table for comparing significant difference between quality of work life and musculoskeletal disorders and the frequency of their qualitative dimensions [37].

In attention to test results given in Table 6, there is a significant difference with 99\% confidence among all qualitative dimensions of musculoskeletal disorders of sample and control society $(\mathrm{P}<0.05$ and null hypothesis is refused against alternative hypothesis) shows positive effect of ergonomic interventions in sample population.

Results of statistical data test related to quality of work life, given in Table 7 show there is no significant difference between control and sample society $(\mathrm{P}>0.05)$ but results of test between data after ergonomic intervention show that there is a significant difference with 99\% confidence between quality of work life of control and sample population ( $\mathrm{P}<0.05$ and null hypothesis is refused against alternative hypothesis) which shows positive effect of ergonomic intervention in sample society. Tests results certify this reality that ergonomic interventions had positive effect in increasing the quality of work life.

\subsection{Comparative Results before and after Total Ergonomics Intervention}

Some of the most important 3-year results ${ }^{3}$ due to total ergonomic interventions to base year (time of start of ergonomic interventions; 2007) have been summarized in Table 8.

In this research, ergonomic interventions process was started with macro-ergonomic interventions and then at the second stage simultaneously focus was moved to

${ }^{3}$ Due to considering magazine rules in pages number, some of the most important results are delivered.
Table 6. Statistical comparisons of qualitative data of musculoskeletal disorders of control and sample community.

\begin{tabular}{|c|c|c|c|}
\hline $\begin{array}{c}\text { Test } \\
\text { no. }\end{array}$ & $\begin{array}{c}\text { Society and time } \\
\text { of testing }\end{array}$ & $\begin{array}{c}\text { P value } \\
\text { Sig (2-tailed) }\end{array}$ & $\begin{array}{c}\chi^{2} \text { Test } \\
\text { result }\end{array}$ \\
\hline 1 & $\begin{array}{l}\text { Control society before intervention } \\
\text { Sample society before intervention }\end{array}$ & 0.591544 & $\begin{array}{l}\text { Without } \\
\text { difference }\end{array}$ \\
\hline 2 & $\begin{array}{l}\text { Sample society after intervention } \\
\text { Sample society after intervention }\end{array}$ & 8.39996E-07 & $\begin{array}{c}\text { Meaningful } \\
\text { difference }\end{array}$ \\
\hline 3 & $\begin{array}{l}\text { Control society before intervention } \\
\text { Control society after intervention }\end{array}$ & $4.22546 \mathrm{E}-16$ & $\begin{array}{c}\text { Meaningful } \\
\text { difference }\end{array}$ \\
\hline 4 & $\begin{array}{l}\text { Sample society after intervention } \\
\text { Control society after intervention }\end{array}$ & 8.53115E-24 & $\begin{array}{c}\text { Meaningful } \\
\text { difference }\end{array}$ \\
\hline
\end{tabular}

Table 7. Comparison of statistical data of work life quality (before and after the ergonomic intervention in sample and control population).

\begin{tabular}{|c|c|c|c|c|c|c|}
\hline \multicolumn{3}{|c|}{$\begin{array}{c}\text { T-test for Equality } \\
\text { of Means }\end{array}$} & \multicolumn{2}{|c|}{$\begin{array}{l}\text { Levine's Test } \\
\text { for Equality } \\
\text { of Variances }\end{array}$} & & \multirow{2}{*}{$\begin{array}{l}\text { Qualitative } \\
\text { dimensions }\end{array}$} \\
\hline $\begin{array}{c}\text { Sig. } \\
\text { (2-tailed) }\end{array}$ & df & $\mathrm{t}$ & Sig. & $\mathrm{F}$ & & \\
\hline 0.000 & 170 & -7.094 & 0.036 & 4.482 & $\begin{array}{l}\text { Equal variances } \\
\text { assumed }\end{array}$ & $\begin{array}{c}\text { No } \\
\text { Discomfort }\end{array}$ \\
\hline 0.000 & 106.974 & -6.610 & & & $\begin{array}{c}\text { Equal variances } \\
\text { not assumed }\end{array}$ & \\
\hline 0.001 & 170 & 3.510 & 0.000 & 16.497 & $\begin{array}{c}\text { Equal variances } \\
\text { assumed }\end{array}$ & $\begin{array}{c}\text { Less } \\
\text { Discomfort }\end{array}$ \\
\hline 0.003 & 88.027 & 3.076 & & & $\begin{array}{l}\text { Equal variances } \\
\text { not assumed }\end{array}$ & \\
\hline 0.000 & 170 & 5.077 & 0.282 & 1.166 & $\begin{array}{c}\text { Equal variances } \\
\text { assumed }\end{array}$ & $\begin{array}{c}\text { Partial } \\
\text { discomfort }\end{array}$ \\
\hline 0.000 & 127.752 & 4.989 & & & $\begin{array}{l}\text { Equal variances } \\
\text { not assumed }\end{array}$ & \\
\hline 0.000 & 170 & 6.212 & 0.000 & 22.796 & $\begin{array}{c}\text { Equal variances } \\
\text { assumed }\end{array}$ & $\begin{array}{c}\text { Much } \\
\text { Discomfort }\end{array}$ \\
\hline 0.000 & 100.611 & 5.681 & & & $\begin{array}{c}\text { Equal variances } \\
\text { not assumed }\end{array}$ & \\
\hline 0.002 & 170 & 3.187 & 0.000 & 23.031 & $\begin{array}{c}\text { Equal variances } \\
\text { assumed }\end{array}$ & $\begin{array}{c}\text { Intolerable } \\
\text { pain }\end{array}$ \\
\hline 0.005 & 93.959 & 2.853 & & & $\begin{array}{l}\text { Equal variances } \\
\text { not assumed }\end{array}$ & \\
\hline
\end{tabular}


Table 8. Comparison of achievements before and after total ergonomic intervention.

\begin{tabular}{|c|c|}
\hline $\begin{array}{l}\text { Sr. } \\
\text { no. }\end{array}$ & Achievement Titles \\
\hline 1 & $\begin{array}{l}\text { Acquiring EO preferred title among } 220 \text { state applied } \\
\text { scientific training centers at the third festival of applied } \\
\text { scientific comprehensive university in country. }\end{array}$ \\
\hline 2 & $\begin{array}{l}500 \% \text { increase of delivering articles in scientific assembles } \\
\text { and foreign and internal research scientific publications. }\end{array}$ \\
\hline 3 & $\begin{array}{l}\text { Getting permit for launching } 18 \text { new courses of studies at } \\
\text { higher-diploma and expertise as compared to base year. }\end{array}$ \\
\hline 4 & $\begin{array}{l}\text { Preparing frame of university and patterns cooperation } \\
\text { society for the first time in higher education of country. }\end{array}$ \\
\hline 5 & $\begin{array}{l}\text { Establishing theater salon by considering ergonomic } \\
\text { principles and using Iranian anthropometry. } \\
\text { (In this project, studying anthropometry has been performed } \\
\text { in field of ergonomic interventions.) }\end{array}$ \\
\hline 6 & $\begin{array}{l}\text { Choosing one of EO lecturers as preferred researcher at the } \\
\text { third festival of technology and knowledge. }\end{array}$ \\
\hline 7 & $\begin{array}{l}\text { Establishing and using multi-apply conference salon by } \\
\text { considering ergonomic principles. }\end{array}$ \\
\hline 8 & $\begin{array}{l}\text { Optimizing human force due to } 50 \% \text { decrease in human } \\
\text { force. }\end{array}$ \\
\hline 9 & $\begin{array}{l}15 \% \text { annual saving of energy cost including gasoil and } \\
\text { electricity. }\end{array}$ \\
\hline 10 & $\begin{array}{l}\text { Executing paperless system in official writings and data } \\
\text { packet. }\end{array}$ \\
\hline 11 & 280\% EO income increase in 2009 as compared to base year. \\
\hline 12 & $\begin{array}{l}30 \% \text { annual increase in personnel income as compared to } \\
\text { base year. }\end{array}$ \\
\hline 13 & Establishing student scientific society with 400 members. \\
\hline 14 & Acquiring distinguished researcher title in related section. \\
\hline 15 & $600 \%$ increase in number of students. \\
\hline
\end{tabular}

micro ergonomic intervention and necessary programming was done. Micro ergonomic interventions in improvements were touched more and were deduced sooner than macro ergonomic changes.

It can be deduced that staff behavior and administrative process and their working method, is not an easy work among administrative personnel and needs more time as compared to engineering and physical changes for getting results.

The most important result of macro-ergonomic changes is organizational culture change, defined as dependent to values governing the organization including those which are not written and customary rules, this culture change is not a sort-term activity but is a calm and continuous improvement process that needs long-term cooperation of staff and management simultaneously. As it was said that major goal of ergonomic interventions is optimizing system at micro and macro levels. Fortunately, conducted analysis in this research shows positive effects of total ergonomic interventions.

\section{References}

[1] M. Shaliza, K. Shahrul, M. Mohzani, O. Zalinda and S. Khairanum, "Application of Quality Function Deployment in Identifying Ergonomics Programs for Malaysian, The Effect of Ergonomics Applications in Work System on Mental Health of Visual Display Terminal Workers Manufacturing Industries," Proceedings in International Conference on Technology Management, 4-5 December 2006, University of Technology Tun Hussien Onn, Malaysia, 2006, pp. 275-277.

[2] A. Kazemi, "Productivity and Its Analysis in Organizations," Organization of Study and Determining Humanistics Sciences Books of Universities (Samt), Tehran, 1981.

[3] N. S. Abarquoei and S. Ahmad, "Place and Role of Human Factors Engineering in Agricultural Sector Productivity," The 1st National Conference of New Technologies in Agriculture and Natural Resources, 4-5 March 2009, Rasht, 2008, pp. 2455-2459.

[4] P. G. Dempsey, "Effectiveness of Ergonomics Interventions to Prevent Musculoskeletal Disorders: Beware of What You Ask," International Journal of Industrial Ergonomics, Vol. 37, No. 2, 2007, pp. 169-173. doi:10.1016/j.ergon.2006.10.009

[5] S. E. Mathiassen, "On the Evolution of Task-Based Analysis of Manual Materials Handling, and Its Applicability in Contemporary Ergonomics," Applied Ergonomics, Vol. 37, No. 1, 2006, pp 33-43. doi:10.1016/j.apergo.2004.11.004

[6] P. Leigh, S. B. Markowitz, M. Fahs, C. Shin and P. J. Landrigan, "Occupational Injury and Illness in the United States, Estimates of Costs, Morbidity, and Mortality," Archives of Internal Medicine, Vol. 157, No. 14, 1997, pp. 1557-1568. doi:10.1001/archinte.1997.00440350063006

[7] G. Pransky, K. Benjamin, C. Hill-Fotouhi, J. Himmelstein, K. E. Fletcher, J. N. Katz and W. G. Johnson, "Outcomes in Work-Related Upper Extremity and Low Back Injuries: Results of a Retrospective Study," American Journal of Industrial Medicine, Vol. 37, No. 4, 2000, pp. 400-409.

doi:10.1002/(SICI)1097-0274(200004)37:4<400::AID-AJ IM10>3.0.CO;2-C

[8] M. Shaliza, S, Kamaruddin, O. Zalinda and M. Mohzani, "The Effect of Ergonomics Applications in Work System on Mental Health of Visual Display Terminal Workers," European Journal of Scientific Research, Vol. 31, No. 3, 2009, pp. 341-354.

[9] P. A. Scott, "Global Inequality, and the Challenge for Ergonomics to Take a More Dynamic Role to Redress the Situation,” Applied Ergonomics, Vol. 39, No. 4, 2008, pp. 495-499. doi:10.1016/j.apergo.2008.02.014

[10] P. A. Scott, "Ergonomicd in Developing Regions, Needs and Applications,” CRC Press, Boca Raton, 2009. doi:10.1201/9781420079128

[11] R. Ford, "Change Your Life Quality (Intellectual Way for Access to Personal Ability and Financial Independence)," Translated by Mehdi Garacheh Daghi, Tehran, 2008.

[12] T. M. Reza, T. Fard, M. Tagi, A. Khalili, Hossein, K. 
Shaei and Safdar, "Re-Designing Environment and Processes for Increasing Productivity and Safety,” 1st International Conference of Ergonomy and Human Factors, 7-8 May 2008, Tehran, pp. 24-25.

[13] W. Hendrick and M. K. Brain, "Macroergonomics Theory, Methods and Applications,” IEA, Mahwah, 2002.

[14] J. Dul and W. P. Neumann, "Ergonomics Contributions to Company Strategies,” Applied Ergonomics, Vol. 40, No. 4, 2009, pp. 745-752. doi:10.1016/j.apergo.2008.07.001

[15] L. Cullen, "Human Factors Integration-Bridging the Gap between System Designers and End-Users: A Case Study,” Safety Science, Vol. 45, No. 5, 2007, pp. 621629. doi:10.1016/j.ssci.2007.01.002

[16] Human Factors and Ergonomics Society (HFES), Human Factors and Ergonomics Society Strategic Plan. Human Factors and Ergonomics Directory and Yearbook, 19992000. Human Factors and Ergonomics Society, Santa Monica, p. 89.

[17] P. W. Neumann, M. Ekman and J. Winkel, “Integrating Ergonomics into Production System Development-The Volvo Powertrain Case,” Applied Ergonomics, Vol. 4, No. 2, 2009, pp. 452-459.

[18] N. Meshkati, “An Etiological Investigation of Micro- and Macroergonomic Factors in the Bhopal Disaster: Lessons for Industries of Both Industrialized and Developing Countries," International Journal of Industrial Ergonomics, Vol. 4, No. 2, 1989, pp. 161-175. doi:10.1016/0169-8141(89)90042-5

[19] P. Carayon, "Human Factors of Complex Sociotechnical Systems,” Applied Ergonomics, Vol. 37, No. 4, 2006, pp. 525-535. doi:10.1016/j.apergo.2006.04.011

[20] M. Motamedzadeh, "Designing and Participatory System Establishment, Its Effect on Organization Productivity and Quality Improvement and Its Comparison with Customary Ergonomics by Guiding Prof. Shahnavaz,” Ph. D Thesis, Tarbiat Moddares University, Tehran, 2003.

[21] W. O. Wing, B. L. Guo, W. Li and D. Yang, "Reducing Conflict in Balanced Scorecard Evaluations," Accounting, Organizations and Society, Vol. 32, No. 4-5, 2007, pp. 363-377.

[22] H. I. Lee, W. C. Chen and C. J. Chang, "A Fuzzy AHP and BSC Approach for Evaluating Industry in Taiwan," Expert Systems with Applications, Vol. 34, No. 1, 2006, pp. 96-107.

[23] B. Andersen, B. Henriksen and W. Aarseth, "Professional Practice Holistic Performance Management: An Integrated Framework," International Journal Productivity and Performance Management, Vol. 55, No. 1, 2006, pp. 61-78. doi:10.1108/17410400610635507

[24] Ö. F. Sarl, "Effects of Employee Trainings on the Occupational Safety and Health in Accommodation Sector," Procedia-Social and Behavioral Sciences, Vol. 1, No. 1, 2009, pp. 1865-1870. doi:10.1016/j.sbspro.2009.01.329
[25] S. Robert, "Performance Evaluation and Control Systems for Executing Strategy,” Translated by Mojtaba Asadi, Aryana in Dastrial Research Group, Tehran, 2006.

[26] L. McAtamney and N. E. Corlett, "RULA: A Survey Method for the Investigation of Work-Related Upper Limb Disorders," Applied Ergonomics, Vol. 24, No. 2, 1993, pp. 91-99. doi:10.1016/0003-6870(93)90080-S

[27] J. S. Moorea and A. Garg, “The Strain Index: A Proposed Method to Analyze Jobs for Risk of Distal Upper Extremity Disorders," American Industrial Hygiene Association Journal, Vol. 56, No. 5, 1995, pp. 443-458. doi:10.1080/15428119591016863

[28] S. Hignett and L. McAtamneyb, "Rapid Entire Body Assessment (REBA),” Applied Ergonomics, Vol. 31, No. 2-3, 2000, pp. 201-205. doi:10.1016/S0003-6870(99)00039-3

[29] P. Drinkaus, R. Sesek, D. Bloswick, T. Bernard, B. Walton and B. Joseph, "Comparison of Ergonomic Risk Assessment Outputs from Rapid Upper Limb Assessment and the Strain Index for Tasks in Automotive Assembly Plants,” Work, Vol. 21, No. 2, 2003, pp. 165-172.

[30] S. Bao, N. Howard, P. Spielholz and B. Silverstein, "Quantifying Repetitive hand Activity for Epidemiological Research on Musculoskeletal Injuries-Part II: Comparison of Different Methods of Measuring Force Level and Repetitiveness,” Ergonomics, Vol. 49, No. 4, 2006, pp. 381- 392. doi:10.1080/00140130600555938

[31] T. Jones and S. Kumar, "Comparison of Ergonomic Risk Assessments in a Repetitive High-Risk Saw Mill Occupation: Saw-Filer," International Journal of Industrial Ergonomics, Vol. 37, No. 9-10, 2007, pp. 744-753. doi:10.1016/j.ergon.2007.05.005

[32] C. Berlin, R. Örtengren, D. Lämkull and L. Hanson, "Corporate-Internal vs. National Standard-A Comparison Study of Two Ergonomics Evaluation Procedures Used in Automotive Manufacturing," International Journal of Industrial Ergonomics, Vol. 39, No. 6, 2009, pp. 940-946.

[33] F. Tayarri and J. I. Smith, "Occupational Ergonomics: Principles and Application,” Chapman \& Hall, London, 1997.

[34] J. Van Lwaarden, T. Van Der Wiele, L. Bell and R. Miller, “Applying SERVQUAL to Websites: An Exploratory Study,” International Journal of Quality Management, Vol. 20. No. 8, 2003, pp. 919-935.

[35] M. Allameh, "Developing Work Life Quality Pattern of Walton Based on Islamic Values,” Ph.D Thesis, Tarbiat Moddares University, Tehran, 1999.

[36] M. Helander, "A Guide to the Ergonomics of Manufacturing,” Taylor \& Francis, Boca Raton, 1995.

[37] A. Rezai and S. A. Meibodi, "Statistics and Probability," Daneshkahi Jahad of Isfahan Technology University, Isfahan, 2005. 